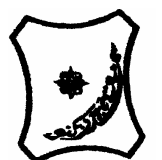

Bayero Journal of Pure and Applied Sciences, 6(1); 164 - 168

Received: September 2012

Accepted: March 2013

ISSN $2006-6996$

\title{
THE EFFECT OF RUBBER EFFLUENT ON SOME CHEMICAL PROPERTIES OF SOIL AND EARLY GROWTH OF MAIZE (ZEA MAYSL)
}

\author{
Orhue, E. R. ${ }^{1}$ and Osaigbovo, A. U. ${ }^{2}$ \\ ${ }^{1}$ Department of Soil Science, Faculty of Agriculture, University of Benin, PMB 1154, Benin City, Nigeria \\ ${ }^{2}$ Department of Crop Science, Faculty of Agriculture, University of Benin, PMB 1154, Benin City, Nigeria \\ Correspondence author: orhuerob@yahoo.com
}

\begin{abstract}
A preliminary pot trial was conducted in a greenhouse to determine the effects of rubber effluent on some soil chemical properties as well as early growth and nutrient uptake by maize plant. The levels of rubber effluent used were 0, 50, 100, 150, 200, $250 \mathrm{ml}$ per $2 \mathrm{~kg}$ soil. The trial was arranged in a completely randomized design and replicated three times. Results showed that the soil $\mathrm{pH}$, organic carbon, $\mathrm{N}, \mathrm{P}, \mathrm{K}, \mathrm{Mg}, \mathrm{Ca} \mathrm{Na}, \mathrm{ECEC}, \mathrm{Fe}, \mathrm{Mn}$ and $\mathrm{Zn}$ were significant/y higher $(\mathrm{P}<0.05)$ in rubber effluent treated soils than the control, while the control was significantly higher in exchangeable acidity. Except $\mathrm{Zn}$, the $\mathrm{N}, \mathrm{P}, \mathrm{K}, \mathrm{Mg}, \mathrm{Ca}, \mathrm{Na}, \mathrm{Fe}, \mathrm{Mn}$ content and their uptake by the plant were significantly higher $(P<0.05)$ in rubber effluent treated plant than the control. The plant height, leaf area and number of leaves were also significantly higher in effluent treated plants than the control. The N, P, K, Mg, Ca, Na content and their uptake and the growth parameters however declined at $200 \mathrm{ml}$ treatment while in Fe, Mn and $\mathrm{Zn}$ content and their uptake, there was no definite pattern of increase with increasing effluent levels. Conclusively, rubber effluent contained vital plant nutrients which may be favorable to soil fertility improvement and maize growth at the application rates.

Keywords: Rubber effluent, maize, nutrient uptake, soil, greenhouse
\end{abstract}

\section{INTRODUCTION}

Rubber is important because its latex is a valuable source of raw materials for numerous items. In addition to being one of the major economic crops in Nigeria, it strengthens the forest cover there by contributing towards continuity of ecological balance. The latex of rubber plant consists of colloidal suspension of rubber particles in an aqueous serum. Thus, natural rubber is an amorphous hydrocarbon, poly-isoprene, which has the property of being highly extensible. The latex also contains many non-rubber constituents such as protein, resins, sugars, glycosides, tannin, alkaloids and mineral salts (Onwueme and Sinha, 1999). The serum phase of the latex according to Seneviratne (1997) is known to constitute $70 \%$ of the total volume and contains large amount of major nutrients required for plant growth. Seneviratne (1997) further reported that the rubber effluent mostly contains an approximate percentage of non-rubber constituents such as carbohydrate (methyl inositol $(2.5 \%)$ ), protein $(1 \%)$, free amino acid $(0.018 \%)$ and other organo nitrogenous bases (chlorine, methyl amine $(0.08 \%)$ ), inorganic anion ( $\left.\mathrm{PO}_{4}{ }^{3-}, \mathrm{CO}_{3}{ }^{2-}\right)$, metallic ions $\left(\mathrm{K}^{+}, \mathrm{Mg}^{2+}, \mathrm{Na}^{+}, \mathrm{Cu}^{2+}\right)$ and formic acid $(0.12 \%)$ used for latex coagulation.

The processing of the latex poses a lot of impacts on the environment. The most suspected noticeable effect is caused by factory effluent which contains a large amount of non-rubber substances in addition to traces of various processing chemicals. The amount of rubber effluent produced in Nigeria has been increasing steadily during the past few years with increase in the number of several processing factories in the country.
The practice of indiscriminate discharge of large volumes of these effluents onto soil and water courses as a means of disposal is wasteful in terms of resource utilization and contradicts the present day agricultural technical development. Also, the abundance of the effluent and the suspected adverse effects on the environment due to the offensive odor pose challenges to agronomist to seek valuable and positive uses for it.

The controlled applications of effluent on land have been reported to cause changes in soil as well as growth of some plants. Yeow and Zin (1981) recorded improved water retention of soil when rubber effluent was used. Poon (1982), Lim and P'ng (1983), Lim et al (1983) reported an increased $\mathrm{pH}, \mathrm{K}$, $\mathrm{Ca}, \mathrm{Mg}$ and organic matter content when rubber effluent was applied. Seneviratne (1997) also observed an increase in soil $\mathrm{N}, \mathrm{P}, \mathrm{K}, \mathrm{Na}, \mathrm{Mg}$ and $\mathrm{Ca}$ in an estate, which had been exposed to rubber effluent for 20 years, while a reduced organic carbon and $\mathrm{Mg}$ was reported for rubber effluent affected soil (Orhue, et al., 2005). Yeow and Yeop (1983) described rubber effluent as excellent soil conditioner.

Effluents have also been reported to have varying effect on plants. The application of block rubber effluent was reported to increase oil palm yield and there was no adverse effects on growth and nutritional status (Lim et al., 1983). The growth of Nupier grass (Tan et al., 1975) and Dialium guineense seedlings (Orhue et al., 2005) were enhanced significantly with rubber effluent. Orhue et al. (2005) reported increased uptake of $\mathrm{N}, \mathrm{P}, \mathrm{Mg}, \mathrm{Na}$ as well as decreased $\mathrm{K}$ uptake by Dialium guineense seedlings with the application of rubber effluent. 
The aim of this trial was to examine the influence of rubber effluent on some soil chemical properties and early growth of maize (Zea mays $L$ ).

\section{MATERIALS AND METHODS}

The trial was conducted in a greenhouse at the experimental site of the Faculty of Agriculture, University of Benin, Benin City, Nigeria. The rubber effluent was obtained from Odia rubber factory, while the Suwan 1 maize variety was obtained from Agricultural Development Project (ADP) both in Benin City. The top soil used was collected from the floor of Gmelina arborea plantation with spade at a depth of 0 $-15 \mathrm{~cm}$. The soil was bulked, mixed thoroughly and a composite sample was made, air-dried and then sieved to remove debris. Thereafter, $2 \mathrm{Kg}$ of the composite soil sample was weighed and put in each of the polythene bags. A total of 36 polythene bags were used. Each replicate had 12 polythene pots. The rubber effluent was applied at the rates of $0,50,100$, 150,200 and $250 \mathrm{ml}$ per $2 \mathrm{Kg}$ soil. The rubber effluent was thoroughly mixed with the soil and then left for 2 weeks to allow for equilibration. The experiment was arranged in a Completely Randomized Design and replicated 3 times. On the day before sowing, the soil was moistened with water. Four seeds of maize were initially sowed and later thinned to one plant per pot at 2 weeks after emergence. Thereafter, the plants were watered every other day with water. Data collection on plant height, number of leaves and leaf area were carried out at 8 weeks after planting. Thereafter the plants were harvested, dried in ventilated oven at $72^{\circ} \mathrm{C}$ for 48 hours to a constant dry weight used in computing nutrient uptake. The nutrient uptake was determined using the product of dry weight $(\mathrm{g})$ of the plant and the nutrient content (\%)

\section{Soil analysis:}

Soil analysis was carried out before and after harvesting of maize plant. The rubber effluent was analyzed before applying it on the soil, while the plant analysis was done at the end of the experiment. Particle size analysis was determined by method of Gee and Or (2002), while the soil pH was determined at a soil to water ratio of $1: 1$ using a glass electrode $\mathrm{pH}$ meter. The $\mathrm{pH}$ of the rubber effluent was read directly from the $\mathrm{pH}$ meter. The electrical conductivity of soil was determined also at a soil to water ratio of $1: 1$ using the CIBA-CORNING conductivity meter whereas the rubber effluent conductivity was read directly from the CIBA-CORNING meter.

The organic carbon content of both soil and rubber effluent was determined by using the chromic acid wet oxidation procedure described by Jackson (1962). The total nitrogen, available phosphorus, exchangeable bases as well as exchangeable acidity were determined using methods of Udo et al. (2009). The effective cation exchange capacity was calculated as the sum of exchangeable bases and exchangeable acidity. The zinc, iron and manganese were determined by methods of Udo et al. (2009).

\section{Plant analysis:}

The plant materials were digested with a mixture of $\mathrm{HNO}_{3}, \mathrm{H}_{2} \mathrm{SO}_{4}$ and $\mathrm{HCIO}_{4}$ acids. The $\mathrm{Na}, \mathrm{K}, \mathrm{Ca}, \mathrm{Mg}$, $\mathrm{Fe}, \mathrm{Mn}$ and $\mathrm{Zn}$ were determined by the use of atomic absorption spectrophotometer. For P content (AOAC, 1990) perchloric acid digestion (wet oxidation) method was used while the micro-kjeldal method of Jackson (1962) was used for $\mathrm{N}$ determination. The data obtained were analysed by Genstat statistical version 6. 1. 0 234. Data collected were subjected to analysis variance (ANOVA). Duncan Multiple Range Test was used in separating the means at $5 \%$ level of probability

\section{RESULTS AND DISCUSSION \\ Properties of rubber effluent:}

The physico-chemical properties of rubber effluent in Table 1 indicated that the effluent was slightly acidic, colorless and contained several elements. The result of the effluent analysis when compared to that of Seneviratne (1997) indicated that most of the parameters are not dependent on the sources of the effluent. The fact is that whatever stage of processing (creep, crumb and concentrate latex) the effluent obtained contains the same basic plant nutrients.

\section{Pre-trial properties of soil used:}

The properties of soil used in the trial were shown in Table 2. The soil was moderately acidic and classified as Ultisol and Benin fasc, grey in color and texturally sandy. Apart from $\mathrm{Mg}$, the $\mathrm{N}, \mathrm{P}, \mathrm{K}$ and $\mathrm{Ca}$ were below the critical values of $1.5-2.0 \mathrm{gkg}^{-1}$ (Sobulo and Osiname, 1981), 10-16 mgkg ${ }^{-1}$ (Adeoye and Agboola, 1985), $0.16-0.25 \mathrm{cmolkg}^{-1}$ (Akinrinde and Obigbesan, 2000) and $2.50 \mathrm{cmolkg}^{-1}$ (Akinrinde and Obigbesan, 2000) respectively. The properties of the soil used indicated that the soil is low in fertility, which is typical of an ultisol as reported earlier by Agboola and Ogunkunle (1993).

\section{Post-trial chemical properties of soil:}

The post-trial properties of the soil are shown in Table 2. The soil pH, organic carbon, $\mathrm{N}, \mathrm{P}, \mathrm{K}, \mathrm{Mg}, \mathrm{Ca}$, $\mathrm{Na}$ and ECEC increased significantly $(P<0.05)$, with increasing levels of rubber effluent while $\mathrm{Fe}, \mathrm{Mn}, \mathrm{Zn}$ and exchangeable acidity increase were not consistent with increasing rubber effluent treatments but significantly higher than the control treatments. The increase in soil $\mathrm{pH}, \mathrm{N}, \mathrm{P}, \mathrm{K}, \mathrm{Mg}, \mathrm{Ca}, \mathrm{Na}, \mathrm{ECEC}$, $\mathrm{Fe}, \mathrm{Mn}, \mathrm{Zn}$ and organic carbon is attributed to the serum properties of the effluent. This increase in soil nutrient content further confirms that applying effluent alone is not problematic especially when the rate of application is geared to supply nutrients at a level corresponding to those in inorganic fertilizers normally applied to promote satisfactory crop performance and that controlled application of effluent causes no detrimental changes in soil, rather it improves soil fertility and has no apparent adverse effect on the environment.

Thus, the beneficial properties of rubber effluent as excellent soil conditioner, makes it a good source of fertilizer. The increased soil organic carbon content is similar to the finding of Lim et al. (1983) and Seneviratne (1997). 
The inconsistent increase in $\mathrm{Fe}, \mathrm{Mn}$ and $\mathrm{Zn}$ content may be attributed to antagonism or nutrient interactions, as earlier reported by $\mathrm{O}^{\prime}$ Conner and Anderson (1974), Loose et al. (1979), Clinton and William (1981), Drewes and Blume (1977) and Remison (1997). The increase in soil $\mathrm{pH}, \mathrm{N}, \mathrm{P}, \mathrm{K}, \mathrm{Ca}$, $\mathrm{Mg}, \mathrm{ECEC}$ and $\mathrm{Na}$ is however similar to the reports of Poon (1982), Lim and P'ng (1983) and Lim et al. (1983).

Effect of rubber effluent on nutrient content uptake by maize plant

The nutrient content of maize in relation to various levels of rubber effluent is shown in Table 3. The $\mathrm{N}$, $\mathrm{P}, \mathrm{K}, \mathrm{Mg}, \mathrm{Ca}, \mathrm{Mn}$ and $\mathrm{Fe}$ content of the rubber effluent treated plants were significantly higher than the control. The trend however was that the N, P, K, $\mathrm{Mg}$ and $\mathrm{Ca}$ increased with increasing rubber effluent levels up to $150 \mathrm{ml}$ and then declined. Non-significant differences were however recorded among the various treatments in $\mathrm{Zn}$ component of the plant. The uptake of nutrient by maize was shown in Table 4 . Except $\mathrm{Zn}$, the $\mathrm{N}, \mathrm{P}, \mathrm{K}, \mathrm{Mg} \mathrm{Fe}, \mathrm{Mn}$ and $\mathrm{Ca}$ uptake were significantly higher $(P<0.05)$ than the control in maize plants treated with rubber effluent. The uptake of $\mathrm{N}, \mathrm{P}, \mathrm{K}, \mathrm{Mg}$ and $\mathrm{Ca}$ however increased with increasing effluent up to $150 \mathrm{ml}$ whereas there was no definite pattern of $\mathrm{Fe}, \mathrm{Mn}$, and $\mathrm{Zn}$ uptake. The increase in nutrient content and uptake by the plant may be attributed to the applied rubber effluent which has higher content of serum. The rubber latex serum phase is known to constitute $70 \%$ of total volume and contains large amount of micro and major nutrients needed for plant growth as earlier reported by Seneviratne (1997). This result is however similar to the findings of Orhue et al. (2005).

\section{and}

Influence of rubber effluent on height, number of leaves and leaf area of maize:

Table 5 shows the influence of rubber effluent of the growth parameters. The height, number of leaves and leaf area of rubber effluent treated maize were significantly higher $(P<0.05)$ than the control treatment. A decline in these growth parameters was however recorded in $200 \mathrm{ml}$ and $250 \mathrm{ml}$ rubber effluent treatments. The increase in plant height, leaf area and number of leaves is attributed to presence of high soil nutrient content provided by the rubber effluent applied. This increase in growth parameters is similar to earlier reports of Lim et al. (1983) in oil palm, Tan et al. (1975) in Nappier grass and Orhue et al. (2005) in Dialium guineense seedlings.

Table 1: Properties of the rubber effluent used in the trial

\begin{tabular}{lc}
\hline Effluent property & Mean value \\
\hline pH & 5.00 \\
Conductivity Scm $\mathrm{C}^{-1}$ & 58.00 \\
Total Nitrogen \% & 2.10 \\
Phosphorus mg/l & 5.26 \\
Organic carbon \% & 0.14 \\
Potassium mg/l & 12.25 \\
Calcium mg/l & 8.82 \\
Sodium mg/l & 1.54 \\
Magnesium mg/l & 2.92 \\
Iron mg/l & 0.04 \\
Manganese mg/l & 0.02 \\
Zinc mg/l & 0.91 \\
\hline
\end{tabular}


Table 2: Chemical properties of soil prior and after the trial

\begin{tabular}{|c|c|c|c|c|c|c|c|c|c|c|c|c|c|}
\hline $\begin{array}{l}\text { Treat. } \\
\mathrm{ml} / 2 \mathrm{~kg} \text { soil }\end{array}$ & pH & $\begin{array}{l}\text { Org } \\
\text { carbon } \\
\text { gkg }^{-1}\end{array}$ & $\begin{array}{l}\text { Total N } \\
\text { gkg }^{-1}\end{array}$ & $\begin{array}{l}\text { P } \\
\text { mgkg }^{-1}\end{array}$ & $\mathbf{K}$ & Mg & $\begin{array}{l}\text { Ca } \\
\text { Cmolkg }^{-1}\end{array}$ & $\mathbf{N a}$ & $\begin{array}{l}\text { Exch } \\
\text { acidity }\end{array}$ & ECEC & $\begin{array}{l}\mathrm{Fe} \\
\leftarrow \\
\end{array}$ & $\begin{array}{l}\text { Zn } \\
\text { mgkg }^{-1}\end{array}$ & Mn \\
\hline & $\begin{array}{l}\text { Before } \\
5.10 \\
\text { After }\end{array}$ & $\begin{array}{l}\text { Planting } \\
13.20 \\
\text { Harvesting }\end{array}$ & 0.5 & 4.71 & 0.04 & 1.39 & 0.01 & 0.08 & 2.08 & 3.52 & 0.01 & 0.09 & 0.05 \\
\hline 0 & $5.14 d$ & $10.04 f$ & $0.04 b$ & $1.91 \mathrm{~d}$ & $0.04 b$ & $1.31 \mathrm{~b}$ & $0.01 b$ & $0.05 d$ & $2.08 a$ & $3.49 d$ & $0.01 \mathrm{c}$ & $0.07 b$ & $0.03 b$ \\
\hline 50 & $6.46 c$ & $13.61 \mathrm{e}$ & $8.60 a$ & $2.48 \mathrm{c}$ & $2.10 a$ & $4.37 a$ & $5.61 \mathrm{a}$ & $1.01 \mathrm{c}$ & $1.40 \mathrm{~b}$ & $14.49 c$ & $0.84 b$ & $0.98 a$ & $0.30 a$ \\
\hline 100 & $6.50 \mathrm{bc}$ & $14.68 d$ & $8.70 a$ & $2.50 \mathrm{c}$ & $2.18 a$ & $4.37 a$ & $6.41 a$ & $1.05 b$ & $1.60 \mathrm{~b}$ & $15.61 b c$ & $0.97 a$ & $0.99 a$ & $0.31 a$ \\
\hline 150 & $6.56 \mathrm{bc}$ & $15.71 \mathrm{c}$ & $8.80 a$ & $2.85 b$ & $2.94 a$ & $4.84 a$ & $6.41 a$ & $1.07 a b$ & $1.60 \mathrm{~b}$ & $15.86 \mathrm{~b}$ & $0.92 a$ & $1.02 \mathrm{a}$ & $0.31 a$ \\
\hline 200 & $6.60 \mathrm{~b}$ & $16.85 b$ & $9.80 a$ & $2.85 \mathrm{~b}$ & $3.03 a$ & $4.84 a$ & $6.41 a$ & $1.09 a$ & $1.40 \mathrm{~b}$ & $16.77 \mathrm{~b}$ & $0.79 b$ & $0.90 \mathrm{~b}$ & $0.30 \mathrm{a}$ \\
\hline 250 & $6.70 \mathrm{a}$ & 18.19a & $10.22 \mathrm{a}$ & $2.99 a$ & $3.29 a$ & $5.86 a$ & $7.21 a$ & $1.09 a$ & $1.60 \mathrm{~b}$ & $19.05 a$ & $0.82 b$ & $0.98 a$ & $0.30 a$ \\
\hline
\end{tabular}

Mean values with the same letter in the column are not significantly different from one another at $P<0.05$.

Table 3: Effect of rubber effluent on the nutrient content of maize plant (\%)

\begin{tabular}{|c|c|c|c|c|c|c|c|c|}
\hline $\begin{array}{l}\text { Treatments } \\
\mathrm{ml} / 2 \text { kg soil }\end{array}$ & $\mathbf{N}$ & $\mathbf{P}$ & $\bar{K}$ & Mg & $\mathrm{Ca}$ & $\mathbf{F e}$ & Mn & $\mathbf{Z n}$ \\
\hline 0 & $1.03 d$ & $0.03 b$ & $1.01 d$ & $0.04 \mathrm{e}$ & $0.02 \mathrm{e}$ & $0.05 d$ & $0.04 b$ & $0.06 a$ \\
\hline 50 & $1.88 \mathrm{c}$ & $0.08 a$ & $1.40 \mathrm{c}$ & $0.10 \mathrm{de}$ & $0.07 c d$ & $0.11 \mathrm{c}$ & $0.09 a$ & $0.07 a$ \\
\hline 100 & $2.06 \mathrm{~b}$ & $0.08 a$ & $1.54 b$ & $0.14 \mathrm{~cd}$ & $0.07 \mathrm{~cd}$ & $0.18 a$ & $0.11 a$ & $0.08 a$ \\
\hline 150 & $2.27 a$ & $0.09 a$ & $1.70 \mathrm{a}$ & $0.64 a$ & $0.11 a$ & $0.14 \mathrm{~b}$ & $0.13 a$ & $0.11 a$ \\
\hline 200 & $2.26 a$ & $0.08 a$ & $1.62 \mathrm{ab}$ & $0.25 b$ & $0.10 a b c$ & $0.11 \mathrm{c}$ & $0.10 a$ & $0.08 a$ \\
\hline 250 & $2.20 \mathrm{a}$ & $0.08 a$ & $1.57 \mathrm{~b}$ & $0.19 b c$ & $0.08 \mathrm{bcd}$ & $0.15 b$ & $0.12 a$ & $0.09 a$ \\
\hline
\end{tabular}

Mean values with the same letter in the column are not significantly different from one another at $P<0.05$.

Table 4: Influence of rubber effluent on Nutrient uptake by maize plant $\left(\mathrm{mgkg}^{-1}\right)$

\begin{tabular}{|c|c|c|c|c|c|c|c|c|}
\hline $\begin{array}{l}\text { Treatments } \\
\mathrm{ml} / 2 \text { kg soil }\end{array}$ & $\mathbf{N}$ & $\mathbf{P}$ & $\mathbf{K}$ & Mg & $\mathrm{Ca}$ & $\mathbf{F e}$ & Mn & $\mathbf{Z n}$ \\
\hline 0 & $26.37 f$ & $8.33 d$ & $8.73 e$ & $11.56 \mathrm{e}$ & $9.66 c$ & $8.67 b$ & $6.33 c$ & $12.00 \mathrm{a}$ \\
\hline 50 & $37.72 \mathrm{e}$ & $13.19 c$ & $12.73 d$ & $21.77 d$ & $14.74 b$ & $17.67 a$ & $13.67 a$ & $14.00 \mathrm{a}$ \\
\hline 100 & $47.33 b$ & $16.47 b c$ & $23.78 c$ & $28.98 c$ & $15.01 \mathrm{~b}$ & $16.67 a$ & $14.33 a$ & $12.00 \mathrm{a}$ \\
\hline 150 & $59.65 a$ & $25.58 a$ & $30.89 a$ & $56.25 a$ & $27.33 a$ & $14.67 a$ & $11.33 b$ & $14.00 \mathrm{a}$ \\
\hline 200 & $43.92 \mathrm{c}$ & $18.73 \mathrm{~b}$ & $26.32 \mathrm{~b}$ & $43.02 \mathrm{~b}$ & $23.91 a$ & $18.00 \mathrm{a}$ & $11.67 \mathrm{~b}$ & $11.33 a$ \\
\hline 250 & $40.91 d$ & $18.57 \mathrm{~b}$ & $23.50 c$ & $31.40 \mathrm{c}$ & $15.69 \mathrm{~b}$ & $20.65 a$ & $15.00 \mathrm{a}$ & $12.00 \mathrm{a}$ \\
\hline
\end{tabular}

Mean values with the same letter in the column are not significantly different from one another at $P<0.05$. 
Table 5: Effect of rubber effluent on maize height, number of leaves and leaf area

\begin{tabular}{llll}
\hline Treatments $\mathbf{~ m l} / 2 \mathbf{~ k g}$ soil & Plant height $\mathbf{( c m )}$ & Leaf area $\left(\mathbf{c m}^{\mathbf{2}}\right)$ & Number of leaves \\
\hline 0 & $15.69 \mathrm{f}$ & $61.30 \mathrm{f}$ & $4.00 \mathrm{f}$ \\
50 & $43.50 \mathrm{e}$ & $80.30 \mathrm{e}$ & $6.69 \mathrm{e}$ \\
100 & $60.50 \mathrm{~d}$ & $91.30 \mathrm{~d}$ & $8.55 \mathrm{~d}$ \\
150 & $84.04 \mathrm{a}$ & $145.90 \mathrm{a}$ & $12.67 \mathrm{a}$ \\
200 & $75.30 \mathrm{~b}$ & $136.20 \mathrm{~b}$ & $10.74 \mathrm{~b}$ \\
250 & $69.32 \mathrm{c}$ & $99.80 \mathrm{c}$ & $8.85 \mathrm{c}$ \\
\hline
\end{tabular}

Mean values with the same letter in the column are not significantly different from one another at $\mathrm{P}<0.05$.

\section{CONCLUSION}

The physiological and nutritional implications of rubber effluent on maize as well as soil chemical properties studied revealed that rubber effluent contained vital plant nutrients which may be favorable

\section{REFERENCES}

AOAC (1990): Association of Official Analytical Chemist. Official methods of analysis $15^{\text {th }}$ ed Washington D.C, USA 66-68

Adeoye, G.O and Agboola A.A (1985): Critical levels for soil $\mathrm{pH}$, available $\mathrm{P}, \mathrm{K}, \mathrm{Zn}$ and $\mathrm{Mg}$ and ear leaf content of $\mathrm{P}, \mathrm{Cu}$ and $\mathrm{Mn}$ in sedimentary soil of South Western Nigeria Fertilizer research 6: 65 $-71$

Agboola, A. A. and Ogunkule, A. O. (1993): Site characterization of Epemakinde, Ondo State, Nigeria. Technical report on land development for sustainable agriculture in Africa. IBSRAM/Africa Land Network, Bangkok, Thailand. $120-131$.

Akinrinde, E. A. and Obigbesan, G. O. (2000): Evaluation of fertility status of selected soil for crop production in five ecological zones of Western Nigeria. Proceeding of the 26th Annual Conference of Soil Science Society of Nigeria. University of Ibadan. October 30 November 3. 279-288

Clinton, C. S. and William, A. W. (1981): Sulfate uptake kinetic of three annual range species. Agronomy Journal 70(1): 35 - 40.

Drewes, H. and Blume, H. P. (1977): Effect of movement and sorption of herbicides in agricultural soils. Forsch Sunderh 33: 104-113.

Gee, G. W. and Or, D. (2002): Particle size distribution: In Dane, J. H., Topp, G. C. (eds). Methods of soil analysis Part 4. Physical methods. Soil Science Society of America book series No. 5 ASA and SSSA. Madison WI. 225-293

Jackson, M. L. (1962): Soil chemical analysis. Prentice Hall. New York.

Lim, K. H. Wood, B. J., and Lal, A. I. (1983): POME on oil palm through flatbed system. Proceeding of seminar on land application of oil palm and rubber factory effluent October 1983. Serdang. 349p.

Lim, K. H. and P'ng, T. C. (1983): Land application of digested palm oil mill effluent by sprinkler system. Proceeding of the seminar on land application of oil palm and rubber factory effluent October 1983. Serdang. 286p.

Loose, M. A., Schcosser, J. F. and Maphany, W. R. (1979): Phenol herbicides degradation on soils. to soil fertility improvement and maize growth at the application rates. Therefore, it could be concluded that rubber effluent has a potential value as fertilizer for maize.

Quantative studies of 2,4 D and MCPA degrading microbial population. Soil Biochemistry 11: 377 - 388.

O'Connor, G. A. and Anderson, J. A. (1994): Soil factors affecting the adsorption of 2,4,5 trichloroacetic acid. Proceeding of the American Soil Science Society 38: 433 - 436.

Onwueme, J. C. and Sinha, T. D. (1999): Field crop production in tropical Africa, $2^{\text {nd }}$ edition. Techniques Center for Agricultural and Rural Cooperation (CTA) Netherlands.

Orhue, E. R., Osaigbovo, A. U. and Osula, O. (2005): Rubber effluent effect on some chemical properties and growth of Dialium guineense seedlings. Journal of Sustainable Agriculture and the Environment. 7(1): $69-82$.

Poon, Y. C. (1982): Recycling of palm oil mill effluent in the field. Proceeding of Rubber Research Institute of Malaysia. Kuala Lumpur, October 1982. 367p.

Remison, S. U. (1997): Basic principles of crop physiology, $1^{\text {st }}$ edition. Published by Sadoh Press, Benin City, Nigeria.

Seneviratne, W. M. G. (1997): Waste water from raw rubber processing industry in Sri Lanka and related environmental aspects. Bull. Rubber Research Institute of Sri Lanka. 35: 42 - 48.

Sobulo, R.A. and Osiname, O. A. (1981): Soils and fertilizer use in Western Nigeria. Research Bulletin. No 11. I.A.R.T University of Ife.

Tan, H. T. and Pillai, K. R. and D. J. Barry (1975): Possible utilization of Rubber factory effluent on crop land. Proceeding of Rubber Reseach Institute of Malaysia. October, Kuala Lunpur, 1975 154p.

Udo, E. J., Ibia, T. O., Ogunwale, J. A., Anuo, A. O. and Esu, I. E. (2009): Manual of soil, plant and water analysis. Sibon books Ltd, Lagos, Nigeria.

Yeow, K. H. and Zin, Z. Z. (1981): Progress report on palm oil mill effluent utilization. Proceeding of the Oil Palm Research Institute of Malaysia on oil palm by product utilization. Kuala Lumpur, $356 \mathrm{p}$

Yeow, K. H. Y. and Yeop, K. A. (1983): The present status effluent in Malaysia. Proceeding of Rubber Research Institute, Malaysia. Pirs Conference Kuala Lumpur. 348p 